\title{
Egy interfész jelenség: indexikális demonstratívumok azonosító fókuszban
}

\author{
Tóth Enikó \\ DE Angol-Amerikai Intézet \\ Csatár Péter \\ DE Germanisztikai Intézet
}

\begin{abstract}
Összefoglaló
Tanulmányunk kiindulópontját egy korábban lefolytatott kísérletünk képezi, amelyben megállapítottuk, hogy az indexikális demonstratívumok használata a kontextus függvényében változik. Az itt bemutatandó kísérlet egyfelöl azt a korábbi eredményünket erősíti meg, hogy ún. semleges kontextusban - az újabban javasolt alternatívákkal szemben - továbbra is a távolság tekinthető a döntő tényezőnek. Másfelöl, kísérletünk továbbviszi a kontrasztáló kontextusok vizsgálatát annak egy altípusára koncentrálva, amikor a kontrasztáló kontextust nyelvileg az azonosító fókusz jelöli. Az eredmények megerősítik, hogy az azonosító fókusz jelöli a kontrasztáló kontextust, mivel a kontrasztáló kontextusban, azaz fókuszpozícióban disztális demonstratívumokat tartalmazó megnyilatkozások elfogadhatósági értéke szignifikánsan magasabb, mint a semleges kontextusú megnyilatkozásoké. Elemzéseink empirikus adatokkal igazolják vissza az azonosító fókusz kommunikatív funkcióját, és rámutatnak arra, hogy az azonosító fókusz - mint interfész jelenség - vizsgálatában produktívan lehet támaszkodni a kísérleti pragmatika eredményeire.
\end{abstract}

Kulcsszavak: proximális és disztális demonstratívumok, távolság, kontextus, kontrasztáltság, kísérletes pragmatika, azonosító fókusz

\section{Bevezetés}

Tanulmányunkban egy olyan kísérlet eredményeit mutatjuk be, amely a magyar indexikális demonstratívumok használatával foglalkozik, és megnyilatkozások elfogadhatósági ítéleteinek mérésén alapszik. Eredményeinkkel azt a feltevést kívánjuk alátámasztani, hogy az indexikális demonstratívumokat tartalmazó megnyilatkozások elfogadhatósági értékei a kontextus természetének függvényében változnak. Vizsgálatunk során két kontextusban, semleges és kontrasztáló kontextusban teszteltük a demonstratívumokat tartalmazó megnyilatkozások elfogadhatósági ítéleteit. A kontrasztáló kontextusnak azonban csak egy altípusa szerepelt a vizsgálatban, mégpedig az, amelyet az azonosító fókusz jelöl a magyarban. Eredményeink egyfelöl hozzájárulnak az indexikális demonstratívumok használatának leírásához, másfelöl empirikus adatokkal igazolják vissza az azonosító fókusz kommunikatív funkcióját, és rámutatnak arra, hogy az azonosító fókusz - mint interfész jelenség vizsgálatában produktívan lehet támaszkodni a kísérleti pragmatika eredményeire. 


\section{A demonstratívumok leírásának újabb irányai}

Az utóbbi időben különböző nyelvek - részben - összehasonlító elemzésével több kutató is arra a következtetésre jutott, hogy megkérdőjelezhető a demonstratívumok (ez/az) használatának hagyományos megközelítése, amely szerint a demonstratívumok megválasztása alapvetően a beszélőtől való távolság tényezőjén alapul (Enfield 2009; Diessel 2012; Coventry-Griffiths-Hamilton 2014). A hagyományos felfogás újragondolását azok a megfigyelések is szükségessé teszik, amelyek a demonstratívumoknak a deiktikus, illetve anaforikus funkcióitól eltérő, a szakirodalomban összefoglalóan „emotívnak” nevezett használatára vonatkoznak, és amelyek szétfeszítik a demonstratívumok funkcióinak hagyományos leírási modelljét. ${ }^{1}$

Azok a törekvések, amelyek igyekeznek egységes keretben kezelni ezeket az eltérő funkciókat, vitatják a távolság tényezőjének elsődlegességét a demonstratívumok megválasztásában. A hozzáférés elmélete (Accessibility Theory, Ariel 2001) szerint a demonstratívumok használatával a beszélő azt jelzi, hogy megítélése szerint mennyire könnyen hozzáférhető a hallgató számára a referált entitás, mégpedig mentális értelemben. Ha a referált entitásnak a beszélő könnyű elérhetőséget tulajdonít, akkor proximális (pl. ez, this) demonstratívumot, ha pedig úgy gondolja, hogy a referált entitás elérése erőfeszítést jelent (mivel az a kontextusban a megítélése szerint váratlannak, fontosnak számít), akkor jellemzően disztális demonstratívumot (pl. az, that) használ. Ehhez hasonló álláspontot fogalmaz meg Gundel et al. (1993) az ismertség hierarchiájának (givenness hierarchy) modelljével, amelyik abból indul ki, hogy a különféle demonstratívumok megválasztása az entitásokra való utaláskor attól függ, hogy milyen kognitív státuszt rendel a beszélő az adott entitáshoz. A proximális demonstratívum az inkább ismert, a disztális pedig az inkább nem ismert entitásokra utalhat ebben a megközelítésben.

Újabban Tóth-Csatár (2014) és Tóth et al. (2014) három nyelvben - a magyarban, az angolban és a hollandban - vizsgálták meg azokat a tényezőket (távolság, elérhetőség, kontrasztáltság), amelyek befolyásolhatják az indexikális demonstratívumok használatát. Végkövetkeztetésük szerint a demonstratívumok mintázata a kontextus típusának (semleges vs. kontrasztáló) függvényében változik. Bővebben, semleges kontextusban a távolság, és nem az elérhetőség ${ }^{2}$ határozza meg az indexikális demonstratívumok használatát, azaz a beszélők proximális demonstratívummal referálnak a hozzájuk közel lévő entitásokra, míg disztális demonstratívummal a távolabbra eső entitásokra utalnak. Ezzel szemben kontrasztáló kontextusokban a távolság mint tényező önmagában nem magyarázza a demonstratívumok használatát.

Ebben a dolgozatban nem kívánunk állást foglalni valamely elmélet mellett, hanem azt vizsgáljuk, hogy közel lévő entitásokra történő utalás esetén semleges kontextusban valóban a távolság-e a döntő tényező, illetve, hogy kontrasztáló kontextusban - szemben a semleges kontextussal, de összhangban az azonosító

\footnotetext{
1 Vö. a demonstratívumok „szimbolikus” (Fillmore 1971), „emocionális” (Lakoff 1974; Chen 1990), „felismerő-azonosító” (Diessel 1999), „együttérző/empatikus” (Cornish 2001) és „affektív" (Riddle 2010) funkcióit, és ezek egységes elméleti keretbe történő beilleszthetőségének problémáit (Scott 2013: 54).

${ }^{2}$ Megjegyzendő, hogy az elérhetőség hipotézisét a szakirodalom több szempontból is - fogalmi kidolgozottság (Burenhult 2003; Hanks 2009), alkalmazhatóság különböző nyelvi példákra (Piwek-Beun-Cremers 2008; Jarbou 2010) - problematikusnak ítéli.
} 
fókusz kontrasztáló funkciójával - az anyanyelvi beszélők a disztális demonstratívumokat tartalmazó megnyilatkozásokat elfogadhatóbbnak találják-e.

\section{A magyar demonstratívumok semleges és kontrasztáló kontextusokban}

\subsection{A demonstratívumok használata a magyarban}

A magyar nyelvben a demonstratívumok két fajtája lelhető fel: ez/ezek (proximálisok), és az/azok (disztálisok). Ezek a demonstratívumok mondattani szempontból vagy önmagukban is DP-t alkotnak, vagy két mellérendelt DP alkot egy értelmező szerkezetet, de végső soron ebben az esetben is egy DP-vel van dolgunk:

(1) Ezt kérem.

(2) Ezt a dinnyét kérem.

(3) Az a futó nyert.

A köznapi nyelvhasználatban a fenti megnyilatkozásokat vélhetőleg egy rámutató gesztus használata kíséri. Ezt a használatot a szakirodalom indexikális használatnak nevezi, amelynek Levinson (2004) két alcsoportját különbözteti meg; a kontrasztáló és a nem kontrasztáló használati módot. (1)-(3) egyike sem kontrasztáló, az alábbi példa viszont igen:

(4) Ezt a fülhallgatót veszem meg, nem azt.

Levinson (2004) ezen felfogását kiterjesztve, valamint Chafe (1994) elemzésére támaszkodva a következőket rögzíthetjük a kontrasztálásról:

(i) a kontrasztálás magában foglalja egy bizonyos jelölt azonosítását egy adott, a szövegelőzményből vagy a beszédhelyzetből kikövetkeztethető halmaz elemei közül;

(ii) a kontrasztálás mint konverzációs jelenség gyakran átível egy beszédforduló határain.

A kontextus fogalmát a hagyományos pragmatikai megközelítések általában négy komponens mentén határozzák meg. Ha elfogadjuk a kontrasztálás fentebbi felfogását, valamint Levinson (2004) fogalmi különbségtételének kiterjesztett változatát a kontrasztáló és a nem kontrasztáló használat között, továbbá figyelembe vesszük azt a tényt, amely szerint a demonstratívumok kétosztatú rendszerei inherensen tartalmazzák a kontraszt lehetőségét (É. Kiss 1998; 2011; Zimmermann 2008; Enfield 2009; Kaiser 2011; Scott 2013), akkor a kontrasztáló kontextusokat a következő négy sajátosság alapján határozhatjuk meg:

(i) fizikális kontextus: nincs megszorítás;

(ii) episztemikus kontextus: a kontrasztált entitások jól ismertek a résztvevők számára;

(iii) diskurzuskontextus: a kontrasztálás explicit módon jelölve van nyelvileg, például kontrasztáló jelentésű mellérendelő kötőszavakkal (de, azonban, viszont), vagy a megnyilatkozásban fellelhető azonosító fókusszal;

(iv) szociális kontextus: nem releváns. ${ }^{3}$

${ }^{3} \mathrm{~A}$ kontextus fogalmához és a kontrasztáló kontextus részletes leírásához I. Csatár-Tóth (2015). 
Azokat a kontextusokat, amelyek nem elégítik ki a fenti definíciót, semleges kontextusoknak fogjuk nevezni. Ahogyan azt egymástól eltérő jellegü kísérleteik eredménye alapján több kutató is megállapítja, a nyelvhasználóknak erős intuíciója van a demonstratívumok használatát illetően (I. például Maes-de Rooij 2007). Tóth et al. (2014) eredményei is azt mutatták, hogy a demonstratívumok eloszlása (azaz a proximálisok és a disztálisok gyakorisága) szignifikánsan eltér semleges és kontrasztáló kontextusokban, ha a referált entitás közel van a beszélöhöz. Jelen dolgozat a kontextusok jellegének hatását vizsgálja tovább: semleges kontextusban a távolság mint tényező szerepét kívánja megerősíteni, továbbá arra vállalkozik, hogy alaposabban megvizsgálja a kontrasztáló kontextusok egyik altípusát, amit nyelvileg a magyar azonosító fókusz jelöl.

\subsection{A magyar demonstratívumok és az azonosító fókusz}

Ahogy az a mondattani kutatásokból jól ismert (É. Kiss 1998; 2003), a magyarban az azonosító fókuszban lévő összetevő közvetlenül az ige előtti pozícióban helyezkedik el és főhangsúlyt visel, azaz a fókusz utáni ige hangsúlytalanná válik. Igekötős igék esetén az igekötő az ige utáni pozícióba kerül, ahogy azt az alábbi példában a válasz is illusztrálja:

- Melyik farmer tetszik a legjobban?

- Azt a kéket próbálom fel.

Az azonosító fókusz szintaktikai és szemantikai tulajdonságairól az újabb elméleti megközelítések többféle módon adnak számot. A szintaktikai elméletek elsősorban arra összpontosítanak, hogy a fókuszban lévő összetevő mozgatását mi váltja ki, a szemantikai elméletek pedig az azonosító fókuszhoz társított sajátos jelentéstartalmat, a kimerítő azonosítást igyekeznek megragadni. Az azonosító fókusz funkciója É. Kiss (1998; 2003) szerint: „A fókusz [...] arra szolgál, hogy kimerítően azonosítsa egy, a szövegelőzményböl vagy a beszédhelyzetből kikövetkeztethető halmaz azon részhalmazát, melyre a VP-ben kifejezett állítás igaz" (É. Kiss 2003: 40).

Az alábbiakban a fókuszhoz társított jelentéstartalomra vonatkozó különböző elméleti megközelítéseket vázoljuk fel röviden. Ezekről általában elmondható, hogy elfogadják a fókusz kimerítő értelmét, azonban azt, hogy ez miképpen jön létre, eltérően magyarázzák. A sztenderdnek tekinthető fókuszelmélet képviselői (Szabolcsi 1981; É. Kiss 1998; Maleczki 2006; Kenesei 1986; 2006; 2009) a kimerítő azonosítást szemantikai jegynek tekintik, azaz a kimerítő azonosítást a fókuszos mondatok igazságfeltételeinek a részeként kezelik. Néhány szerző azonban újabban megkérdőjelezte ezt a felfogást; Wedgwood (2005) például relevanciaelméleti keretben amellett érvel, hogy a kimerítő azonosítás implikatúraként kezelendő, Balogh (2009) pedig kötelező implikatúraként értelmezi a fókusz kimerítő értelmezését inkvizitív szemantikai megközelítésben.

Újabban empirikus tanulmányok is kétségbe vonták a sztenderd szintaktikaiszemantikai elemzésnek a fókusz kimerítő jegyére vonatkozó feltevését. KasLukács (2013) gyerekek és felnőttek részvételével igazságérték-megítélési teszt alapján vizsgálta, hogy érzékenyek-e az azonosító fókusz által kifejezett kimerítő azonosításra. Eredményeik a felnőttek esetében azt mutatják, hogy a felnőttek 
érzékenyek a fókusz által kifejezett kimerítő azonosításra, bár azon kontextusokban, amikor nincs szó kimerítő azonosításról, meglepően nagy arányban fogadják el a fókuszos mondatokat. Ezzel szemben kísérletük alapján a gyerekek esetében egyáltalán nem beszélhetünk fókusz iránti érzékenységről, azaz úgy tűnik, a gyerekek nem képesek arra, hogy megkülönböztessék egymástól a fókuszt tartalmazó, illetve nem tartalmazó mondatok jelentését. Mind a gyermekek, mind a felnőttek figyelemreméltó inkonzisztenciát produkáltak a fókuszos és nem fókuszos mondatok értelmezése során. Kas-Lukács (2013) tehát úgy véli, hogy kísérleti eredményeik ellentmondanak a sztenderd szintaktikai-szemantikai elmélet kimerítő azonosításra vonatkozó feltevésének, és inkább összevethetők a pragmatikai alapokon nyugvó megközelítésekkel.

Hasonló eredményről számolnak be Gerőcs, Babarczy és Surányi (2014), akik két kísérlet során vizsgálták a fókuszhoz társított kimerítő azonosítást. GerőcsBabarczy-Surányi (2014) úgy vélik, hogy a magyar azonosító fókusz, az angol szétszakított szerkezetekkel szemben (cleft sentences), amit általában a magyar azonosító fókusz megfelelőjének tartanak, nem hordoz inherens kimerítő jegyet, azaz a kimerítő azonosítás nem része a mondat igazságfeltételeinek, és amellett érvelnek, hogy inkább pragmatikai implikatúraként, mégpedig konvencionális implikatúraként kezelendő.

Kurrens tanulmányaiban É. Kiss a fókuszos mondatokat specifikációs állításként kezeli (É. Kiss 2006; 2011), és a fókusz kimerítő jegyét a fókuszmozgatással létrehozott specifikációs szerkezet szemantikai következményének tekinti. Ebben a megközelítésben a fókusz specifikáló predikátum, melynek alanya a fókuszt követő mondatszakasz, ami egy nyitott mondat. Ekkor a fókusz funkciója úgy írható le, hogy specifikálja, azaz referenciálisan azonosítja a nyitott mondat által meghatározott halmazt, mégpedig úgy, hogy felsorolja annak elemeit (É. Kiss 2006; 2011).

Összességében megállapíthatjuk tehát, hogy bár a fókuszhoz társított kimerítő azonosítást a különböző elméletek másképpen elemzik, valamilyen módon (inherensen, implikatúraként, következményként) a fókuszos mondatok értelmezése során létrejön a kimerítő azonosítás.

Már É. Kiss (1998) is rámutat arra, hogy az azonosító fókusz [„kontrasztív] lehet. ${ }^{4}$ É. Kiss (1998) alapján az azonosító fókusz [+kontrasztív]-nak minősül, ha az alternatívahalmaza véges, és a diskurzus résztvevői számára ennek az alternatívahalmaznak az elemei ismertek. Ebben az esetben ugyanis a véges alternatívahalmaz két diszjunkt részhalmazra osztható fel; az egyik az azonosító fókusz által jelölt halmaz, a másik pedig a vele kontrasztált halmaz, a fókusz által jelölt halmaz komplementerhalmaza, amely elemei az alternatívahalmaz véges volta miatt egyértelműen azonosíthatók. A komplementerhalmaz elemeire a mondatban kifejezett álítás hamis lesz. Nyilvánvaló, hogy az alternatívahalmaznak legalább két elemet kell tartalmaznia (Surányi 2011), hiszen a kontrasztálás csak így jöhet létre.

Hasonló álláspontot képvisel Molnár (2011), aki a mondat információstruktúrájának tipológiai vizsgálata során Gundel-Hedberg-Zacharski (1993) ismertséghierarchiájából kiindulva létrehoz egy kontraszthierarchiát, amelyen elhelyezi az

\footnotetext{
${ }^{4}$ Az azonosító fókusz jellemzésekor a generatív irodalom megkülönböztet explicit és implicit kontrasztot tartalmazó kontextust (ezekről bővebben I. Surányi 2011). Az ebben a tanulmányban bemutatandó kísérlet során É. Kiss (1998) kontrasztivitásfogalmát követjük.
} 
azonosító fókuszt is. A hierarchia azt mutatja, hogy az azonosító fókusz kontrasztáló funkciója akkor a legerősebb, amikor az alternatívahalmaz egyértelműen adott a kontextusból. Az azonosító fókusznak ezt a tulajdonságát a kísérlet tervezése során is figyelembe vettük.

\section{A kísérlet}

\subsection{A kísérlet felépítése és az alkalmazott módszerek}

Mint korábban már utaltunk rá, Tóth-Csatár-Banga (2014) kimutatták, hogy semleges kontextusban a távolság játszik döntő szerepet a demonstratívumok megválasztásakor, illetve hogy a semleges kontextusokhoz képest kontrasztáló kontextusokban megnövekszik a disztálisok aránya, holott a referált entitások mind közel vannak a beszélöhöz; vagyis a távolság kontrasztáló kontextusokban önmagában nem képes megmagyarázni a demonstratívumok eloszlását. Az alábbiakban bemutatandó kísérlet egyfelől a távolság szerepére vonatkozó eredményeinket kívánja megerősíteni semleges kontextusokban, amelyekben a referált entitások mindig közel vannak a beszélöhöz. Másfelöl, kísérletünk azt az elméleti feltevést teszteli, amely szerint az azonosító fókusz által jelölt kontextusok a kontrasztáló kontextusok egyik altípusának tekinthetők. Ezt úgy vizsgáltuk, hogy korábbi kísérletünkre (Tóth-Csatár-Banga 2014) támaszkodva disztális demonstratívumokat szerepeltettünk fókuszpozícióban. Vagyis azt teszteltük, hogy van-e eltérés az alábbi megnyilatkozások megítélése között:

- indexikális disztális demonstratívumok azonosító fókuszban (kontrasztáló kontextus)

versus

- $\quad$ indexikális disztális demonstratívumok fókusz nélküli megnyilatkozásokban (semleges kontextus).

Korábbi eredményeink alapján azt vártuk, hogy a fókuszos megnyilatkozások, ahol disztális demonstratívum van a fókuszban, magasabb értékítéleteket kapnak, mint a disztálisokat nem fókuszpozícióban tartalmazó, azaz semleges kontextusúnak tekintett megnyilatkozások. Tehát a vizsgált hipotézisek a következők:

\section{Hipotézis 1 (távolság)}

Semleges kontextusban a beszélöhöz közel lévő entitásokra való utaláskor az indexikális proximális demonstratívumokat tartalmazó megnyilatkozások magasabb értékítéleteket kapnak, mint az indexikális disztális demonstratívumokat tartalmazó megnyilatkozások.

\section{Hipotézis 2 (kontrasztálás)}

A beszélőhöz közel lévő entitásokra való utaláskor az indexikális disztális demonstratívumokat fókuszban tartalmazó kontrasztív kontextusú megnyilatkozások magasabb értékítéleteket kapnak, mint az indexikális disztális demonstratívumokat nem fókuszpozícióban tartalmazó semleges kontextusú megnyilatkozások.

A fenti hipotézisek tesztelésére egy online kérdöívet állítottunk össze. A résztvevőknek az volt a feladatuk, hogy kérdésekre adott válaszok elfogadhatóságát 
négyfokozatú Likert-skálán ${ }^{5}$ értékeljék. A lehető legnagyobb megbízhatóság érdekében tesztünkben „gazdag kontextusokat” alkalmaztunk (Meibauer 2012): a tesztmondat egy mini dialógus része volt, a dialógust egy narratív mondat vezette fel, és egy kép egészítette ki (I. 1. ábra). A dialógusokban szereplő kérdés mindig nyitott, kiegészítendő kérdés volt. Úgy véljük, hogy a használt kérdések, illetve képek önmagukban nem teremtik meg a kontrasztálás lehetőségét, anélkül, hogy a kontrasztálás nyelvileg jelölve lenne (l. 2. szakasz). Tehát a fő különbség a kétféle kontextus között az, hogy semleges kontextusokban a kontrasztáltság a fenti értelemben nyelvileg egyáltalán nincs jelölve. Mivel online kérdőíves módszert használtunk, ezért nem hagyatkozhattunk a hangsúlyra sem, ami a beszélt nyelvben egyértelműen jelöli az azonosító fókuszt. A tesztmondataink ezért igekötős igéket tartalmaztak, ugyanis ezek esetében az azonosító fókuszt írásban is világosan jelöli az igekötő elmozgatása a posztverbális pozícióba. Ez egyúttal maga után vonja a kimerítő olvasat kötelező voltát (Balogh 2009).

A gazdag kontextusok alkalmazása azt is lehetővé tette, hogy a fókuszos mondatok specifikációs állitásként történő kezelésével összhangban (É. Kiss 2011) egy rásegítő inger megjelenítésével segítsük az azonosító fókusz specifikációs funkciójának érvényesülését, azaz a fókusz által specifikált halmaz elemeinek referenciális azonosítását. A rásegítő inger azt a szerepet töltötte be, hogy nyilvánvalóvá tegye a nyitott mondat által meghatározott halmaz és a komplementer halmaz elemei közti különbséget (I. például a zsiráfok közti különbséget - a kötést az egyik zsiráf lábán - az 1. ábrán). Természetesen a semleges kontextusokat ugyanezen elvek mentén hoztuk létre (I. a kenyér és a jegesmedvék elhelyezését a 2. ábrán).

A két gondozó délután az állatorvoshoz készül a zsiráfokkal.

- Melyik zsiráfot visszük el délután az állatorvoshoz?

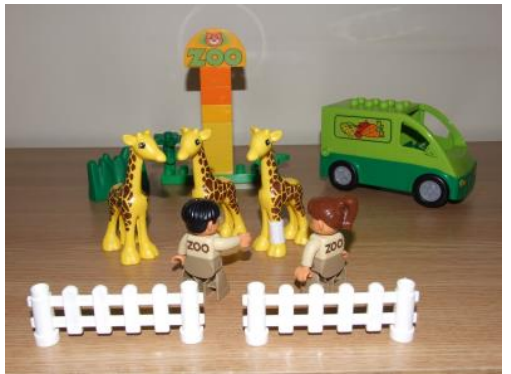

- Azt a zsiráfot (rámutat) visszük el.

$\bigcirc$ teljesen elfogadhatatlan

○ 3 kevésbé elfogadható
O 2 kevésbé elfogadhatatlan

$\bigcirc 4$ teljesen elfogadható

1. ábra

Kontrasztáló kontextus

${ }^{5}$ Ezt a módszert gyakran a kényszerített választás eszközének (forced choice method) is nevezik. 
A kontextuális információ minél sokrétübb prezentálására képeket is használtunk a tesztben, melyeken Lego DUPLO figurák jelenítettek meg egy-egy állatkerti szituációt. Ily módon a fizikális kontextus viszonyrendszere (beszélő, címzett, referált entitások, egyéb entitások elhelyezkedése) világosan kivehető volt a kontextusból, továbbá minden referált entitás közel volt a beszélőhöz. A mini dialógusok résztvevői szintén láthatók voltak a képeken, miként az a rámutató gesztus is, ami a főnévi mutató névmások indexikális használatát kísérte, függetlenül a kontextus típusától. A rámutató gesztus meglétére a szövegben is expliciten utaltunk. A tesztben szereplő egyik kontrasztáló kontextust mutatja be az 1. ábra, míg a 2. ábrán egy semleges kontextus látható.

Az új gondozót körbevezetik az állatkertben. A jegesmedvéknél az új gondozó megkérdezi:

- Mit csináltál az előbb a medvéknél?

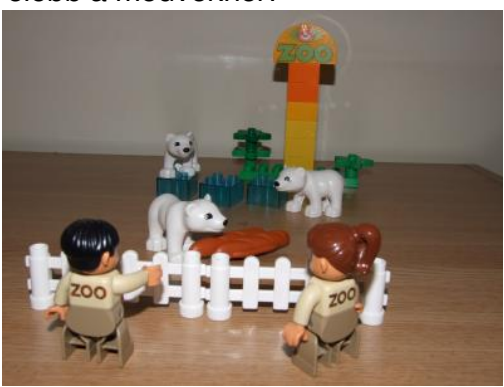

- Ezt a jegesmedvét (rámutat) odacsaltam a száraz kenyérhez.

$\bigcirc 1$ teljesen elfogadhatatlan

○ kevésbé elfogadható
○ 2 kevésbé elfogadhatatlan

$\bigcirc 4$ teljesen elfogadható

2. ábra

Semleges kontextus

Kísérletünkben két változó hatását vizsgáltuk, a kontextus jellege: Łkontrasztáló, illetve az indexikális demonstratívum típusa: „proximális. Ennek megfelelően a tesztmondatok négy kondícióban szerepeltek, egyenként négy tesztelemmel. ${ }^{6}$ Például a fenti tesztelem az 1. ábrán (+kontrasztáló, -proximális), a 2. ábrán pedig (-kontrasztáló, +proximális) tesztelem látható. Ezen felül a teszt 8 disztraktor kontextust is tartalmazott, amelyek nem különböztek a fenti példáktól felépítésük tekintetében. A tesztben előzetesen véletlen sorrendben rendeztük el az tesztelemeket és a disztraktorokat, de az egyes kitöltők a kérdőíves módszernek megfelelően mindig ugyanabban a sorrendben töltötték ki a tesztet.

A kísérletben 36 magyar anyanyelvü beszélő vett részt, akiket hólabda módszerrel választottunk ki. Mindannyian a Debreceni Egyetem alapszakos hallgatói voltak, átlagéletkoruk 22 év volt. A résztvevők nem tudták, hogy mi a kísérlet célja.

${ }^{6}$ Mivel a szakirodalomban felmerült, hogy különbség lehet az alanyi és tárgyi fókuszra való érzékenység között (I. Kas-Lukács 2013), ezért ennek a tényezőnek a lehetséges hatását minimalizálandó a tesztben fele-fele arányban szerepeltek az alanyi és tárgyi fókuszos mondatok. 


\subsection{Eredmények és diszkusszió}

Az első hipotézis tesztelésére semleges kontextusban vetettük össze a -kontrasztáló, „proximális megnyilatkozások értékítéleteit az előjelpróba segítségével. Vagyis megvizsgáltuk, hogy semleges kontextusban a proximális, illetve a disztális demonstratívumokat tartalmazó megnyilatkozások milyen értékítéleteket kaptak (a referált entitások mindig a beszélőhöz közel helyezkedtek el). A próba alapján szignifikáns eltérés van a -kontrasztáló, „proximális megnyilatkozások között ( $z=$ $-2,00, p<0,05)$; vagyis, amikor semleges kontextusban a beszélőhöz közel lévő entitásra történik utalás, a proximális demonstratívumokat tartalmazó megnyilatkozások összességében többször kaptak magasabb (3-as és 4-es) elfogadhatósági értéket a skáláról (I. 1-2. táblázat, 3. ábra). A távolság tehát valóban döntő szerepet játszik a demonstratívumok használatában, hiszen közel levő entitásokra való utaláskor (semleges kontextusban) a proximális demonstratívumokat tartalmazó megnyilatkozások bizonyultak elfogadhatóbbnak a négyfokozatú Likert-skála alapján.

\begin{tabular}{|l|l|l|}
\hline Értékítéletek & Gyakoriságok & Relatív gyakoriságok (\%) \\
\hline 1 & 17 & $12 \%$ \\
\hline 2 & 22 & $15 \%$ \\
\hline 3 & 41 & $28 \%$ \\
\hline 4 & 64 & $45 \%$ \\
\hline összesen: & 144 & $100 \%$ \\
\hline
\end{tabular}

1. táblázat

A -kontrasztáló, +proximális kondíció 4 teszteleméhez a kitöltők által hozzárendelt értékítéletek megoszlása

\begin{tabular}{|l|l|l|}
\hline Értékítéletek & Gyakoriságok & Relatív gyakoriságok (\%) \\
\hline 1 & 21 & $15 \%$ \\
\hline 2 & 30 & $21 \%$ \\
\hline 3 & 41 & $28 \%$ \\
\hline 4 & 52 & $36 \%$ \\
\hline összesen: & 144 & $100 \%$ \\
\hline
\end{tabular}

2. táblázat

A -kontrasztáló, -proximális kondíció 4 teszteleméhez a kitöltők által hozzárendelt értékítéletek megoszlása

Ez az eredmény összhangban van korábbi kísérletünk eredményeivel (Tóth-CsatárBanga 2014), bár most csak közel lévő entitásokra való utalást vizsgáltunk eltérő designnal. Ezért az itt bemutatott eredmények módszertani szempontból erősebb, ún. konvergáló evidenciát szolgáltatnak a távolság mint döntő tényező mellett. Hasonló következtetéseket vonnak le Coventry et al. (2008) az angol nyelvre, illetve Luz-Van der Sluis (2011) az angol, holland és portugál nyelvre vonatkozóan. 


\section{Semleges kontextusok}

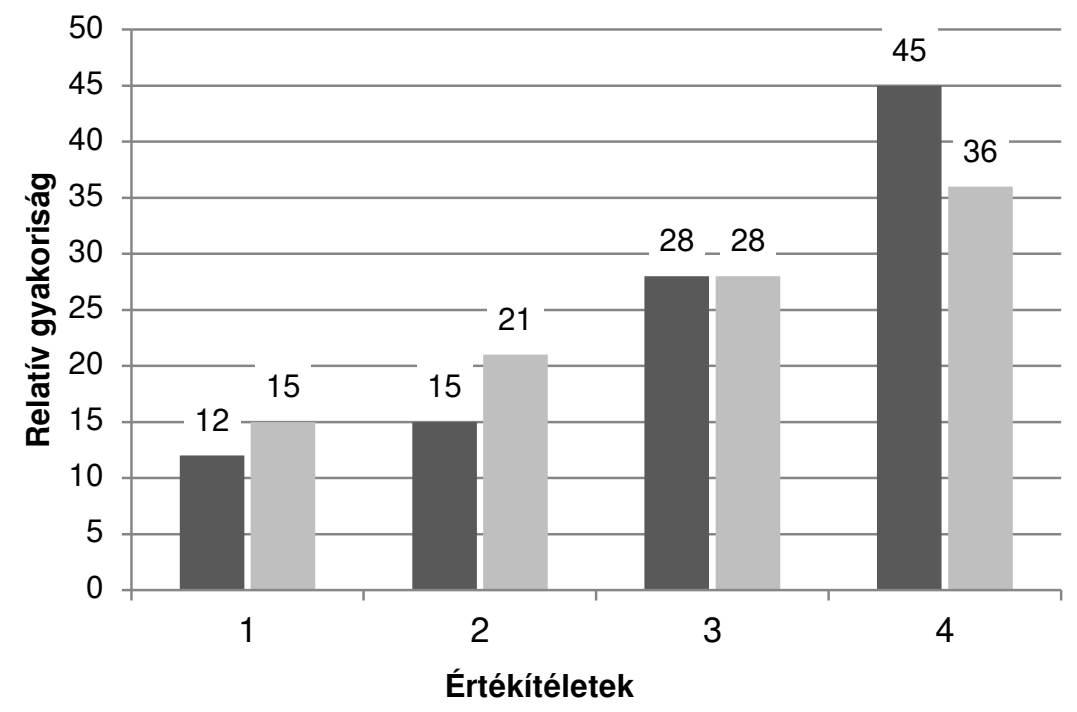

a proximális disztális

3. ábra

Az értékítéletek relatív gyakorisága a -kontrasztáló, „proximális kondíciókban

A második hipotézis teszteléséhez a kapott értékítéleteket a Friedman teszt segítségével elemeztük. A kapott eredmény a négyféle kondíció között szignifikáns eltérést mutat $\left(\chi^{2}(3)=21,85, p<0,01\right)$. Ezután post-hoc teszteket (előjelpróbát) végeztünk. Először a -proximális megnyilatkozások értékítéleteit vetettük össze semleges és kontrasztáló kontextusokban. A post-hoc teszt eredménye szintén szignifikáns $(z=-4,25, p<0,01)$. Az adatok részletesen a 3-4. táblázatban és a 4 . ábrán láthatók. Megfigyelhetjük, hogy mivel közel levő entitásokra történik utalás, semleges kontextusban a disztális demonstratívumokat tartalmazó megnyilatkozások viszonylag alacsony értékítéleteket kapnak a távolság döntő szerepe miatt. Ugyanakkor, szintén közel levő entitásokra való utaláskor szignifikánsan magasabb ítéleteket kaptak azok a megnyilatkozások, amelyekben disztálisok vannak fókuszpozícióban. ${ }^{7}$ Ez arra enged következtetni, hogy kontrasztáló kontextusban, amelyet jelen esetben az azonosító fókusz jelöl, a távolság mint faktor önállóan nem képes megmagyarázni a demonstratívumok használatát.

${ }^{7}$ Megjegyzendő, hogy leíró szempontból ez a kondíció az egyetlen, amikor a módusz, azaz a leggyakrabban választott érték a legmagasabb érték, azaz 4 volt. Ez azt jelenti, hogy a beszélők ebben a kondícióban ítélték a legelfogadhatóbbnak a megnyilatkozásokat, azaz a kontrasztáló, disztálisokat fókuszpozícióban tartalmazó megnyilatkozások a beszélők szerint a legelfogadhatóbbak. 


\begin{tabular}{|l|l|l|}
\hline Értékítéletek & Gyakoriságok & Relatív gyakoriságok (\%) \\
\hline 1 & 21 & $15 \%$ \\
\hline 2 & 30 & $21 \%$ \\
\hline 3 & 41 & $28 \%$ \\
\hline 4 & 52 & $36 \%$ \\
\hline összesen: & 144 & $100 \%$ \\
\hline
\end{tabular}

3. táblázat

A -kontrasztáló, -proximális kondíció 4 teszteleméhez a kitöltők által hozzárendelt értékítéletek megoszlása

\begin{tabular}{|l|l|l|}
\hline Értékítéletek & Gyakoriságok & Relatív gyakoriságok (\%) \\
\hline 1 & 9 & $6 \%$ \\
\hline 2 & 18 & $12 \%$ \\
\hline 3 & 34 & $24 \%$ \\
\hline 4 & 83 & $58 \%$ \\
\hline összesen: & 144 & $100 \%$ \\
\hline
\end{tabular}

4. táblázat

A +kontrasztáló, -proximális kondíció 4 teszteleméhez a kitöltők által hozzárendelt értékítéletek megoszlása

\section{Semleges és kontrasztáló kontextusok}

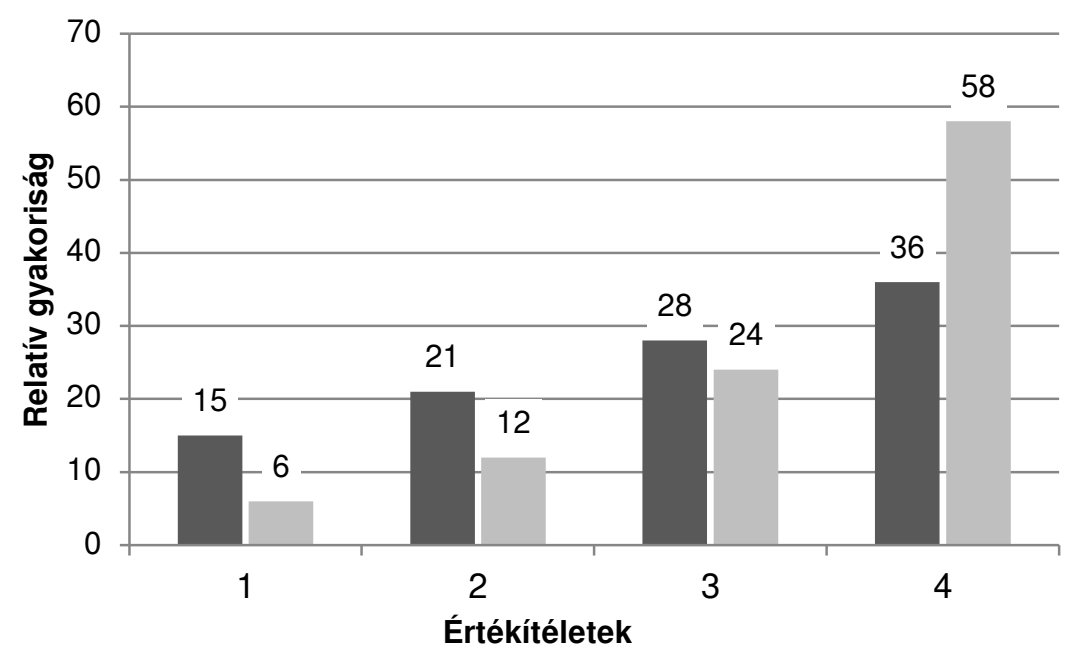

ø semleges kontrasztáló

2. ábra

Az értékítéletek relatív gyakorisága a „kontrasztáló, -proximális kondíciókban 
A +proximális megnyilatkozás-párok hasonló szempontból elvégzett vizsgálata szerint ( \pm kontrasztáló, +proximális) nincs szignifikáns különbség a semleges és kontrasztáló kontextusok között. Nem is vártunk szignifikáns különbséget, hiszen a beszélők mindig közel lévő entitásokra mutattak rá a képeken, azaz a +proximális megnyilatkozásoknál magas értékeket vártunk a hagyományos felfogás alapján.

A (+kontrasztáló, „proximális) kondíciók összevetése szintén nem mutat szignifikáns különbséget. Az utolsó két teszt eredménye megengedi azt a stipulációt, hogy kontrasztáló kontextusban a disztális demonstratívum mellett a proximális is elfogadható, feltéve, hogy a referált entitás közel van a beszélöhöz. Ha ugyanis a disztálisok lennének a kontrasztálás egyedüli eszközei, akkor szignifikáns eltérést kellett volna tapasztalnunk a +kontrasztáló, „proximális kondíciók esetén. Ugyanakkor ismét bebizonyosodott, hogy a távolság kontrasztáló kontextusban önmagában nem döntő faktor, hiszen nem képes megmagyarázni a kapott értékítéleteket.

A fenti stipuláció összhangban van Levinson (2000) felfogásával, aki amellett érvel, hogy az angol nyelvben a demonstratívumok skaláris kontrasztot alkotnak $\langle$ this, that $\rangle$. „Ez azt jelzi elöre, hogy a that használati köre szélesebb, és potenciálisan egybeeshet a this használati körével, és úgy tünik, ez valóban így is van" (Levinson 2000: 94). ${ }^{8}$

\section{Következtetések}

Kísérletünk eredményei megerősítik a korábbi vizsgálódásainkból levont következtetéseinket: az indexikális demonstratívumok használata függ a kontextus típusától. Semleges kontextusban visszaigazolódott a távolság döntő szerepe, kontrasztáló kontextusokban pedig, amikor disztális névmások szerepelnek a fókuszban - feltétel: a referált entitás közel van a beszélőhöz -, a megnyilatkozások magasabb értékítéleteket kapnak, mint a semleges kontextusban szereplő, a disztálisokat nem fókuszban tartalmazó megnyilatkozások. Kísérletünk tehát megerősíti azt, hogy az azonosító fókusz kontrasztáló kontextust jelez, azaz empirikusan visszaigazolja a szintaktikai elméletek felfogását a fókusz kontrasztív jellegéről.

\section{Köszönetnyilvánítás}

A kutatást az Országos Tudományos Kutatási Alapprogramok (OTKA) K 111918 nyilvántartási számú projektje támogatta.

\section{Hivatkozások}

Ariel, Mira 2001. Accessibility theory. An overview. In Ted Sanders - Joost Schilperoord - Wilbert Spooren (szerk.) Text Representation: Linguistic and Psycholinguistic Aspects. Amsterdam: John Benjamins Publishing Company. 29-87.

Balogh, Kata 2009. Theme with Variations. A Context-based Analysis of Focus. Amsterdam: Universiteit van Amsterdam.

8 „This predicts that that has a wide distribution, potentially overlapping with this, as indeed seems to be the case." 
Burenhult, Niclas 2003. Attention, accessibility, and the addressee: The case of the Jahai demonstrative ton. Pragmatics 13/3-4:363-379.

Chafe, Wallace L. 1994. Discourse, Consciousness, and Time. The Flow and Displacement of Conscious Experience in Speaking and Writing. Chicago, London: University of Chicago Press.

Chen, Rong 1990. English demonstratives. A case of semantic expansion. Language Sciences 12/2-3:139-153.

Cornish, Francis 2001. „Modal” that as determiner and pronoun. The primacy of the cognitive-interactive dimension. English Language and Linguistics 5/2:297-315.

Coventry, Kenny R. - Debra Griffiths - Colin J. Hamilton 2014. Spatial demonstratives and perceptual space. Describing and remembering object location. Cognitive Psychology 69:46-70.

Coventry, Kenny R. - Berenice Valdés - Alejandro Castillo - Pedro Guijarro-Fuentes 2008. Language within your reach. Near-far perceptual space and spatial demonstratives. Cognition 108/3:889-895.

Csatár Péter - Tóth Enikő 2015. Az indexikális főnévi mutató névmások kontextuális használata. In Bódog Alexa - Csatár Péter - Németh T. Enikő (szerk.) Használat és hatás. Budapest: Loisir Könyvkiadó. (megjelenés alatt).

Diessel, Holger 1999. Demonstratives. Form, Function and Grammaticalization. Amsterdam: John Benjamins Publishing Company.

Diessel, Holger 2012. Deixis and demonstratives. In Claudia Maienborn - Klaus von Heusinger - Paul Portner (szerk.) An International Handbook of Natural Language Meaning Vol. 3. Berlin, Boston: De Gruyter. 2407-2431.

É. Kiss, Katalin 1998. Identificational focus versus information focus. Language 74/2:245-273.

É. Kiss Katalin 2003. Mondattan. In É. Kiss Katalin - Kiefer Ferenc - Siptár Péter Új magyar nyelvtan. Budapest: Osiris Kiadó. 17-186.

É. Kiss Katalin 2006. Érvek és ellenérvek a fókusz [+kimerítő] jegyével kapcsolatban. In Kálmán László (szerk.) KB 120. A titkos kötet. Nyelvészeti tanulmányok Bánréti Zoltán és Komlósy András tiszteletére. (Segédkönyvek a nyelvészet tanulmányozásához 60). Budapest: MTA Nyelvtudományi Intézet, Tinta Könyvkiadó. 317-335.

É. Kiss Katalin 2011. Szerkezetileg kódolt előfeltevés a magyar mondatszerkezetben. In Bartos Huba (szerk.) Általános Nyelvészeti Tanulmányok XXIII. Új irányok és eredmények a mondattani kutatásban. Budapest: Akadémiai Kiadó. 245263.

Enfield, Nick J. 2009. The Anatomy of Meaning. Speech, Gesture, and Composite Utterances. Cambridge: Cambridge University Press.

Fillmore, Charles J. 1971. Towards a Theory of Deixis. In Charles J. Fillmore Lectures On Deixis. Reprint. 1997. Stanford: CSLI Publications.

Gerőcs, Mátyás - Anna Babarczy - Balázs Surányi 2014. Exhaustivity in focus. Experimental evidence from Hungarian. In Joseph E. Emonds - Markéta Janebová (szerk.) Language Use and Linguistic Structure. Proceedings of the Olomouc Linguistics Colloquium 2013. (Olomouc Modern Language Series 3). Olomouc: Palacký University. 181-194.

Gundel, Jeanette K. - Nancy Hedberg - Ron Zacharski 1993. Cognitive status and the form of referring expressions in discourse. Language 69/2:274-307. 
Hanks, William F. 2009. Fieldwork on deixis. Journal of Pragmatics 41/1:10-24.

Jarbou, Samir Omar 2010. Accessibility vs. physical proximity. An analysis of exophoric demonstrative practice in spoken Jordanian Arabic. Journal of Pragmatics 42/11:3078-3097.

Kaiser, Elsi 2011. Salience and contrast effects in reference resolution. The interpretation of Dutch pronouns and demonstratives. Language and Cognitive Processes 26/10:1587-1624.

Kas, Bence - Ágnes Lukács 2013. Focus sensitivity in Hungarian adults and children. Acta Linguistica Hungarica 60/2:217-245.

Kenesei, István 1986. On the logic of word order in Hungarian. In Werner Abraham - Sjaak de Meij (szerk.) Topic, Focus and Configurationality. Amsterdam: John Benjamins Publishing Company. 143-159.

Kenesei, István 2006. Focus as identification. In Valéria Molnár - Susanne Winkler (szerk.) The Architecture of Focus. Berlin: Mouton de Gruyter. 137-168.

Kenesei, István 2009. Quantifiers, negation, and focus on the left periphery in Hungarian. Lingua 119/4:564-591.

Lakoff, Robin 1974. Remarks on this and that. CLS 10. Chicago: Chicago Linguistic Society. 345-356.

Levinson, Stephen C. 2000. Presumptive Meanings: The Theory of Generalized Conversational Implicature. Cambridge: The MIT Press.

Levinson, Stephen C. 2004. Deixis. In Laurence Horn - Gergory Ward (szerk.) The Handbook of Pragmatics. Oxford: Wiley-Blackwell. 97-121.

Luz, Saturnino - lelka van der Sluis 2011. Production of demonstratives in Dutch, English and Portuguese dialogues. In Claire Gardent - Kristina Striegnitz (szerk.) Proceedings of the 13th European Workshop on Natural Language Generation. Stroudsburg: Association for Computational Linguistics. 181186.

Maes, Alfons - Christ de Rooij 2007. (How) Do demonstratives code distance? In António Branco - Tony McEnery - Ruslan Mitkov - Fátima Silva (szerk.) DAARC 2007. 6th Discourse Anaphora and Anaphor Resolution Colloquium. Lagos: Centro de Linguistica da Universidade de Porto. 83-89.

Maleczki Márta 2006. Kérdések és válaszok a fókusz szemantikájáról. In Kálmán László (szerk.) KB 120. A titkos kötet. Nyelvészeti tanulmányok Bánréti Zoltán és Komlósy András tiszteletére. (Segédkönyvek a nyelvészet tanulmányozásához 60). Budapest: MTA Nyelvtudományi Intézet, Tinta Könyvkiadó. 37-48.

Meibauer, Jörg 2012. What is a context? Theoretical and empirical evidence. In Rita Finkbeiner - Jörg Meibauer - Petra B. Schumacher (szerk.) What is a Context? Linguistic Approaches and Challenges. Amsterdam, Philadelphia: John Benjamins Publishing Company. 9-32.

Molnár Valéria 2011. „Fundamentális” kérdések az információstruktúrában univerzális és tipológiai megfigyelések tükrében. In Bartos Huba (szerk.) Általános Nyelvészeti Tanulmányok XXIII. Új irányok és eredmények a mondattani kutatásban. Budapest: Akadémiai Kiadó. 15-49.

Piwek, Paul - Robbert-Jan Beun - Anita Cremers 2008. „Proximal” and „distal” in language and cognition. Evidence from deictic demonstratives in Dutch. Journal of Pragmatics 40/4:694-718. 
Riddle, Elizabeth M. 2010. Vantage Theory and the use of English demonstrative determinerswith proper nouns. Language Sciences 32/2:225-240.

Scott, Kate 2013. This and that. A procedural analysis. Lingua 131:49-65.

Surányi Balázs 2011. A szintaktikailag jelöletlen fókusz pragmatikája. In Bartos Huba (szerk.) Általános Nyelvészeti Tanulmányok XXIII. Új irányok és eredmények a mondattani kutatásban. Budapest: Akadémiai Kiadó. 281-313.

Szabolcsi, Anna 1981. Compositionality in focus. Folia Linguistica 15/1-2:141-162.

Tóth Enikő - Csatár Péter 2014. A főnévi mutató névmások indexikális használatát befolyásoló tényezők a magyarban. Jelentés és Nyelvhasználat 1:67-85.

Tóth, Enikő - Péter Csatár - Arina Banga 2014. Exploring Hungarian and Dutch gestural demonstratives. In Ludmila Veselovská - Markéta Janebová (szerk.) Complex Visibles Out There. (Olomouc Modern Language Monographs 4). Olomouc: Palacký University. 607-625.

Wedgwood, Daniel 2005. Shifting the Focus. From Static Structures to the Dynamics of Interpretation. Oxford: Elsevier.

Zimmermann, Malte 2008. Contrastive focus and emphasis. Acta Linguistica Hungarica 55/3-4:347-360.

\section{A szerzőkről}

Tóth Enikő a Debreceni Egyetem Angol-Amerikai Intézetének egyetemi adjunktusa. Főbb kutatási területei a mód és a modalitás, a szemantika és a nyelvelsajátítás, valamint a kísérletes pragmatika.

Elérhetősége: toth.eniko@arts.unideb.hu

Csatár Péter a Debreceni Egyetem Germanisztikai Intézetének egyetemi docense. Főbb kutatási területei a metafora és a figuratív nyelvhasználat pragmatikája és a nyelvészeti metaforaelméletek módszertani kérdései.

Elérhetősége: csatar.peter@arts.unideb.hu 